\title{
DEVELOPMENT OF A SREX FLOWSHEET FOR THE SEPARATION OF STRONTIUM FROM DISSOLVED INEEL ZIRCONIUM CALCINE
}

\author{
J. D. Law \\ D. J. Wood \\ T. A. Todd
}




\title{
Development of a SREX Flowsheet for the Separation of Strontium from Dissolved INEEL Zirconium Calcine
}

\author{
J. D. Law \\ D. J. Wood \\ T. A. Todd
}

Published January 1999

Idaho National Engineering and Environmental Laboratory

High Level Waste Program

Lockheed Martin Idaho Technologies Company

Idaho Falls, Idaho 83415

Prepared for the

U.S. Department of Energy

Assistant Secretary for Environmental Management

Under DOE Idaho Operations Office

Contract DE-AC07-94ID13223 


\begin{abstract}
Laboratory experimentation has indicated that the SREX process is effective for partitioning ${ }^{90} \mathrm{Sr}$ from acidic radioactive waste solutions located at the Idaho Nuclear Technology and Engineering Center. These laboratory results were used to develop a flowsheet for countercurrent testing of the SREX process with dissolved pilot plant calcine. Testing was performed using 24 stages of $2-\mathrm{cm}$ diameter centrifugal contactors which are installed in the Remote Analytical Laboratory hot cell. Dissolved Run \#64 pilot plant calcine spiked with ${ }^{85} \mathrm{Sr}$ was used as feed solution for the testing. The flowsheet tested consisted of an extraction section (0.15 M 4',4'(5')-di-(tert-butylcyclohexo)-18-crown-6 and 1.5 $M$ TBP in Isopar- ${ }^{\circledR}$ ), a $1.0 M \mathrm{NaNO}_{3}$ scrub section to remove extracted $\mathrm{K}$ from the SREX solvent, a $0.01 M \mathrm{HNO}_{3}$ strip section for the removal of $\mathrm{Sr}$ from the SREX solvent, a $0.25 M \mathrm{Na}_{2} \mathrm{CO}_{3}$ wash section to remove degradation products from the solvent, and a $0.1 M \mathrm{HNO}_{3}$ rinse section. The behavior of ${ }^{85} \mathrm{Sr}, \mathrm{Na}, \mathrm{K}$, $\mathrm{Al}, \mathrm{B}, \mathrm{Ca}, \mathrm{Cr}, \mathrm{Fe}, \mathrm{Ni}$, and $\mathrm{Zr}$ was evaluated. The described flowsheet successfully extracted ${ }^{85} \mathrm{Sr}$ from the dissolved pilot plant calcine with a removal efficiency of $99.6 \%$. Distribution coefficients for ${ }^{85} \mathrm{Sr}$ ranged from 3.6 to 4.5 in the extraction section. With these distribution coefficients a removal efficiency of approximately $>99.99 \%$ was expected. It was determined that the lower than expected removal efficiency can be attributed to a stage efficiency of only $60 \%$ in the extraction section. Extracted $\mathrm{K}$ was effectively scrubbed from the SREX solvent with the $1.0 \mathrm{M} \mathrm{NaNO}_{3}$ resulting in only $6.4 \%$ of the K in the HLW strip product. Sodium was not extracted from the dissolved calcine by the SREX solvent; however, the use of a $1.0 \mathrm{M} \mathrm{NaNO}_{3}$ scrub solution resulted in a $\mathrm{Na}$ concentration of $70 \mathrm{mg} / \mathrm{L}$ (12.3\% of the feed concentration) in the HLW strip product. $\mathrm{Al}, \mathrm{B}, \mathrm{Ca}, \mathrm{Cr}, \mathrm{Fe}, \mathrm{Ni}$, and $\mathrm{Zr}$ were determined to be essentially inextractable.
\end{abstract}




\section{ACKNOWLEDGEMENTS}

The authors would also like to express their appreciation to Troy Garn, Carl Lundholm, Rich Tillotson, and Earlen Wade for their assistance with laboratory testing, operation of the centrifugal contactors, chemical makeup, and sample preparations.

Many thanks to Lee Hinckley of the Radiochemical Analysis Group, and Jeff Laug, Duane Lundholm, and Dennis Nielsen of the Spectrochemical Analysis Group for the efficient, expedient sample analyses.

Without the work and dedication of these people, this test could not have proceeded. 


\section{CONTENTS}

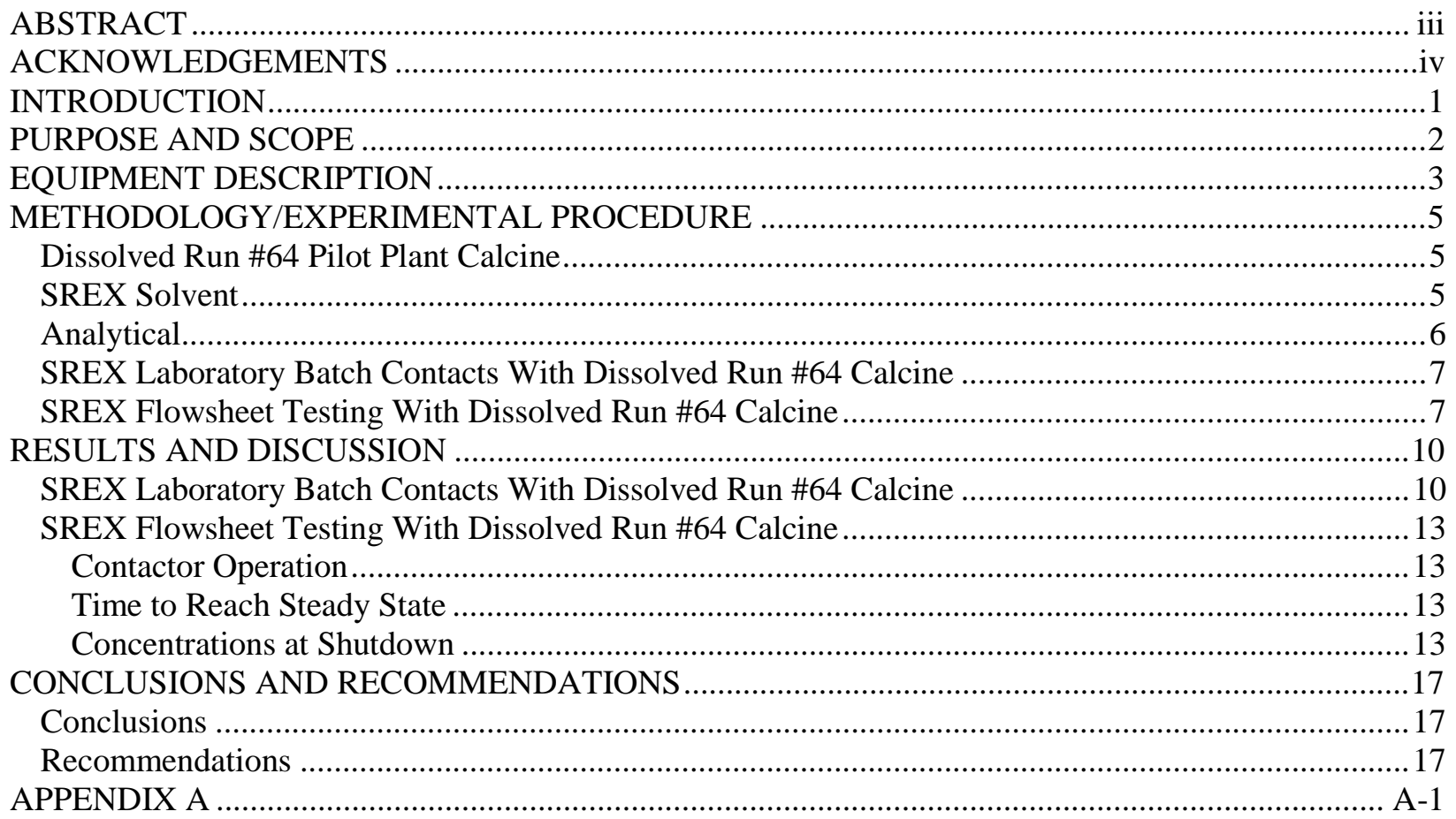




\section{TABLES}

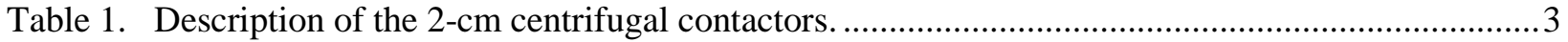

Table 2. Dissolved Run \#64 pilot plant calcine SREX feed composition ................................................5

Table 3. Concentrations (mg/L) of Aqueous Phase Metals in Batch Contacts. ......................................12

Table 4. Estimated Distribution Coefficients for Components in Batch Contacts.................................12

Table 5. Mass Percentages of Metal Ions in Aqueous Solutions. .......................................................... 12

Table 6. Flowrates and O/A ratios for SREX flowsheet testing with dissolved Run \#64 calcine............. 13

Table 7. Percentage of component in each of the effluent streams for SREX flowsheet testing with

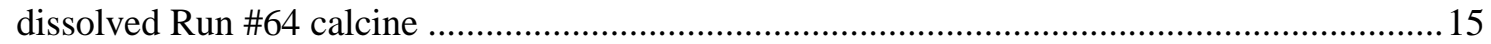

Table 8. ${ }^{85} \mathrm{Sr}$ distribution coefficients for SREX flowsheet testing with dissolved Run \#64 calcine........ 16

\section{FIGURES}

Figure 1. 2-cm diameter centrifugal contactors installed in the RAL shielded cell .................................. 4

Figure 2. SREX batch contact flowsheet with dissolved Run \#64 calcine............................................. 8

Figure 3. Flowsheet for SREX testing with dissolved Run \#64 calcine ............................................... 9

Figure 4. Dependence of $\mathrm{K}(\diamond)$ and $\mathrm{Sr}(\mathbf{\square})$ Extraction on hydronium ion concentration. Aqueous phase: $3.5 M$ nitrate ion with $0.001 M \mathrm{KNO}_{3}$ or $0.001 M \mathrm{Sr}\left(\mathrm{NO}_{3}\right)_{2}$, adjusted with $\mathrm{LiNO}_{3}$

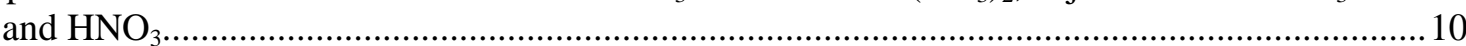

Figure 5. ${ }^{85} \mathrm{Sr}$ approach to steady state in the aqueous raffinate and strip product................................. 14

Figure 6. Comparison of experimental aqueous phase activities with GTM predicted activities for each of the extraction stages as a function of stage efficiency................................................ 14 


\section{Development of a SREX Flowsheet for the Separation of Strontium from Dissolved INEEL Zirconium Calcine}

\section{INTRODUCTION}

The Idaho Nuclear Technology and Engineering Center (INTEC), previously known as the Idaho Chemical Processing Plant (ICPP), formerly reprocessed spent nuclear fuel to recover fissionable uranium. The radioactive raffinates from the solvent extraction uranium recovery processes were converted to granular solids (calcine) in a high temperature $\left(500^{\circ} \mathrm{C}\right)$ fluidized bed. Currently, there are $4136 \mathrm{~m}^{3}$ of calcine temporarily stored at the INTEC. The calcine can be characterized as either aluminum type calcine (generated from aluminum fuel reprocessing raffinates) or zirconium type calcine (generated from zirconium fuel reprocessing raffinates). Both calcine types are $<1 \mathrm{wt} \%$ in transuranic (TRU) and fission product content.

Treatment of the INTEC calcine inventories by dissolving the calcine, partitioning the radionuclides, and immobilizing the resulting high-level and low-level waste streams is currently under evaluation. The aqueous raffinates resulting from the separation processes would be grouted and disposed of as non-TRU low-level waste (LLW). The resulting fractions containing the TRUs and fission products would be vitrified and disposed of as high-level waste (HLW) glass. The primary benefit of the radionuclide partitioning option is a significant HLW glass volume reduction. Based on available data, direct vitrification of the entire $4136 \mathrm{~m}^{3}$ of INTEC calcine would generate approximately $9,000 \mathrm{~m}^{3}$ of HLW glass, while the separation of the TRUs and fission products would result in less than $700 \mathrm{~m}^{3}$ of HLW glass. ${ }^{1}$ A recent peer review identified the most promising radionuclide separation technologies for evaluation. ${ }^{2}$ The Transuranic Extraction process, developed by Horwitz and Schulz, ${ }^{3}$ was identified as a primary candidate for separation of the actinides from INTEC waste. The Strontium Extraction (SREX) process, developed by Horwitz ${ }^{4-6}$, was identified as a primary candidate for separation of ${ }^{90} \mathrm{Sr}$ from INTEC waste.

A major emphasis at the ICPP has been directed toward evaluating ${ }^{90} \mathrm{Sr}$ separation from dissolved calcine using the SREX process. The active extractant used in the SREX process solvent is 4',4'(5')-di(tert-butylcyclohexo)-18-crown-6 (DtBuCH18C6). Tributylphosphate (TBP) is added to the solvent as a phase modifier to prevent third phase formation and a paraffinic hydrocarbon is used as a diluent. Considerable laboratory scale experimentation has been performed to evaluate the extraction properties of the SREX solvent with INTEC sodium-bearing waste (generated primarily from equipment decontamination and solvent wash activities) and dissolved calcine, and to develop a SREX flowsheet. ${ }^{7-10}$ Testing of the SREX process with simulated sodium-bearing waste (SBW) in 5.5-cm centrifugal contactors resulted in $99.98 \%$ removal of $\mathrm{Sr}^{9,10}$ With the test, $\mathrm{Pb}$ was extracted into the SREX solvent and selectively stripped from the solvent with a second strip section (ammonium citrate). Based on the results of the laboratory and pilot-scale testing, a SREX flowsheet demonstration was performed using 24 stages of 2-cm diameter centrifugal contactors. ${ }^{11}$ More recently, efforts have focused on development of the SREX process for the treatment of dissolved INTEC zirconium calcine. This development effort has resulted in the recent flowsheet testing of the SREX process using a dissolved zirconium calcine simulant spiked with ${ }^{85} \mathrm{Sr}$ and 24 stages of centrifugal contactors. The results of the laboratory and flowsheet testing are the primary focus of this report. 


\section{PURPOSE AND SCOPE}

The purpose of this study was to develop and test a SREX flowsheet which will effectively extract and strip ${ }^{90} \mathrm{Sr}$ from dissolved INTEC zirconium calcine under continuous, countercurrent conditions. Specifically, reduction of the ${ }^{90} \mathrm{Sr}$ activity to below the NRC Class A LLW limit of $0.04 \mathrm{Ci} / \mathrm{m}^{3}$ is desired. Also, it is advantageous to minimize the quantity of inert elements in the HLW strip product in order to minimize the final HLW glass volume. The scope of this study was to develop a SREX flowsheet based on laboratory batch contact testing and to evaluate the following items for the flowsheet under continuous countercurrent conditions in a 2-cm centrifugal contactor pilot plant.

- Determine if the $\mathrm{Sr}$ extraction and recovery is sufficient to reduce to ${ }^{90} \mathrm{Sr}$ activity to below the NRC Class A LLW requirement of $0.04 \mathrm{Ci} / \mathrm{m}^{3} .{ }^{85} \mathrm{Sr}$ was added to dissolved pilot plant calcine to evaluate the behavior of ${ }^{90} \mathrm{Sr}$. Also, evaluate the distribution coefficients of Sr throughout the flowsheet.

- Determine the extent of extraction of the metals, such as $\mathrm{Na}$ and K. Evaluate the distribution coefficients of the metals and the effectiveness of the scrub section in removing the extracted metals from the SREX solvent.

- Evaluate the effectiveness of the strip section in removing extracted $\mathrm{Sr}$ and metals from the SREX solvent.

- Evaluate the overall physical properties of the flowsheet to determine if flooding or precipitate formation occurred in any sections of the flowsheet. 


\section{EQUIPMENT DESCRIPTION}

The flowsheet testing was performed using $2-\mathrm{cm}$ diameter centrifugal contactors installed in the CPP-684 Remote Analytical Laboratory (RAL) shielded hot cell. The 2-cm centrifugal contactors, as shown in Figure 1, consist of 24 stages of 2-cm diameter centrifugal contactors, feed and receiving vessels, feed pumps, and an air purge system for the contactor bearings. The aqueous and organic feed pumps and feed vessels were located inside the shielded cell. The remaining feed pumps and feed vessels were located outside the cell. All of the feed pump controllers were located outside the cell. Nonradioactive solutions used for the flowsheet testing were pumped to the centrifugal contactors through penetrations in the cell wall.

The centrifugal contactors were designed and fabricated by Argonne National Laboratory (ANL). The centrifugal contactors were designed specifically for operation of the TRUEX process with ICPP waste. The contactors were modified at the ICPP for remote installation and operation in the RAL hot cell. Specifically, a modified support structure was fabricated for the contactors. This support structure is portable to allow the contactors to be moved out of the way when not in operation, contains leveling screws to adjust for unevenness in the cell floor, and can be disassembled into three sections. It was necessary to design the support structure for disassembly and reassembly so that the structure would fit through the $12 \mathrm{in.} \mathrm{by} 22 \mathrm{in.} \mathrm{glove} \mathrm{box} \mathrm{access} \mathrm{port} \mathrm{into} \mathrm{the} \mathrm{cell} \mathrm{and} \mathrm{be} \mathrm{assembled} \mathrm{remotely.} \mathrm{The}$ centrifugal contactors were also installed through the access port in groups of four and assembled on the support structure remotely. Lifting bails were installed on each contactor to facilitate remote replacement or inspection of any motor/rotor assemblies. A description of the centrifugal contactors is provided in Table 1.

Solution was fed to the contactors using valveless metering pumps. Surge lines, consisting of 4-inch sections of 1-inch stainless steel tubing, were placed on the outlet of the pumps to dampen the surging flow. Because of the difficulty associated with remote installation, surge lines were not installed for the aqueous and organic feed pumps located in cell. Flowrates were adjusted by controlling the pump speed using a ten-turn potentiometer or by manually adjusting the piston stroke length.

Clear, flexible Teflon or Teflon lined Tygon tubing was used for inlet and outlet connections to the feed and receiving vessels. The feed lines were $1 / 8$ in. o.d. tubing and the product lines were $3 / 8$ in. o.d. tubing.

Table 1. Description of the 2-cm centrifugal contactors.

\begin{tabular}{ll} 
Size & 2-cm rotor diameter \\
Motor & 115 Volt, $60 \mathrm{~Hz}$ Bodine Model 710 \\
RPM & $3,600 \mathrm{rpm}$ (not adjustable) \\
Material of construction & 304L stainless steel \\
Inlet and outlet ports & 3/8 in. o.d. tubing \\
Configuration & $\begin{array}{l}\text { Single stage units which can be configured as } \\
\text { desired. Stages are connected using U- tubes. }\end{array}$ \\
\hline
\end{tabular}




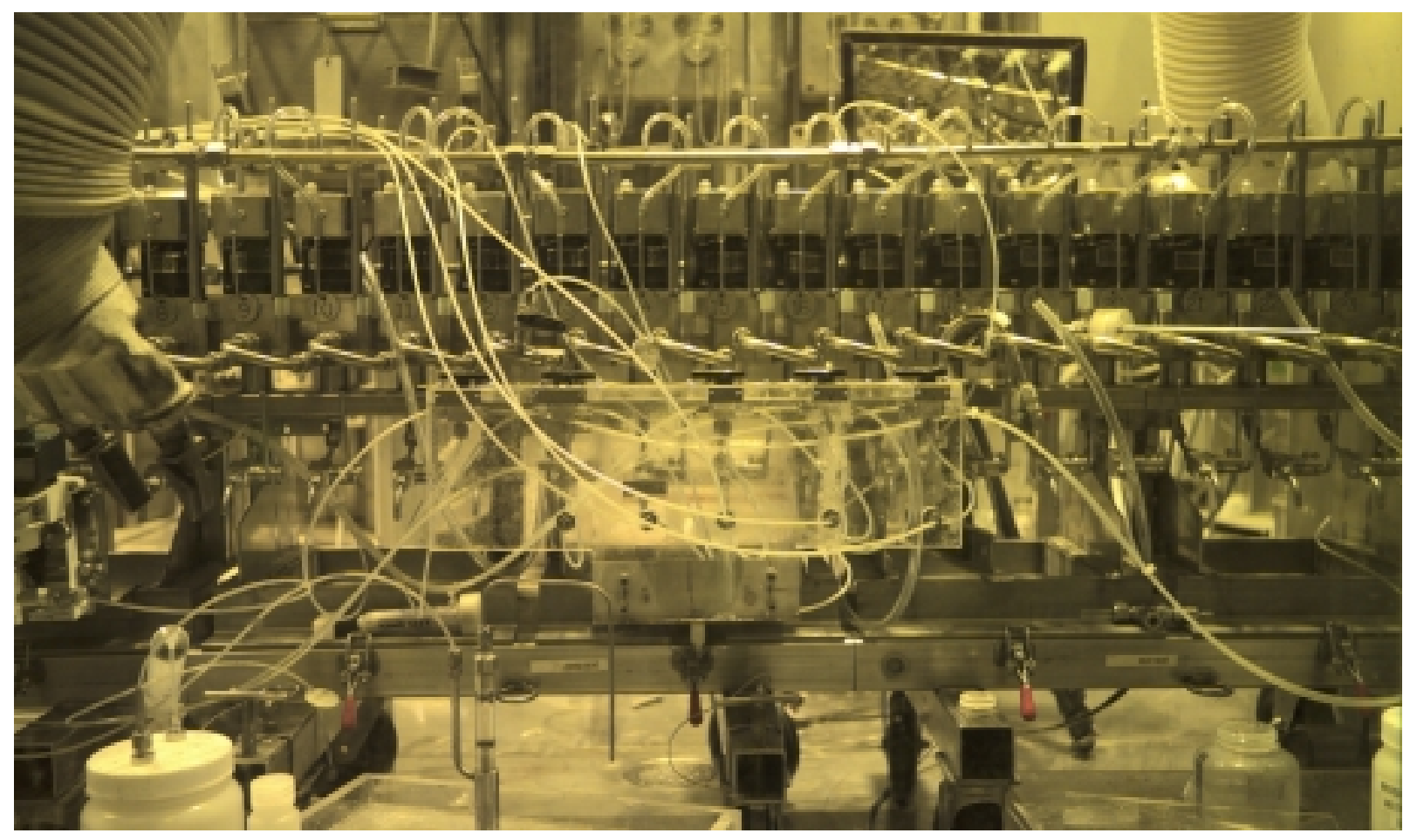

Figure 1. 2-cm diameter centrifugal contactors installed in the Remote Analytical Laboratory shielded cell.

The 2-cm centrifugal contactors do not have provisions for sampling the aqueous and organic solutions exiting individual stages during operation. The aqueous raffinate, strip product, wash effluent, and solvent recycle streams were sampled by routing the solution draining to a receiving vessel into a sample bottle during the actual flowsheet test. Individual stage samples were taken by draining the contactor stages after shutdown.

An air purge system was connected to the contactor bearing housings. Purge air was required in order to protect the motor body, shaft, and bearings from corrosive process fumes. Air to the bearing housings passed through a rotameter. The air flowrate through the rotameter could be adjusted from zero to five scfh. Air from the rotameter was split to feed each of the 24 contactors. The diameter of the air manifold was large ( $1 / 2$ in. o.d. tubing), while the diameter of the tubes leading from the manifold to the contactors was small (1/8 in. o.d. tubing), resulting in the airflow to each contactor being approximately equivalent. The offgas from the bearing purge system was vented to the cell. 


\section{METHODOLOGY/EXPERIMENTAL PROCEDURE}

\section{Dissolved Run \#64 Pilot Plant Calcine}

For the batch contact and flowsheet testing, the behavior of ${ }^{85} \mathrm{Sr}$ and the non-radioactive components in dissolved Run \#64 pilot plant calcine was evaluated. Run \#64 pilot plant calcine was selected as the representative zirconium calcine for use in development testing. It should be noted that Run \#64 calcine was chosen instead of Run \#74 calcine, which was used for the development of the TRUEX process, ${ }^{12}$ due to the excessive concentrations of stable $\mathrm{Sr}$ in the Run \#74 calcine. The excessive stable strontium concentration in the Run \#74 calcine is not representative of the actual Sr concentration in INTEC zirconium calcine and will adversely effect the performance of the SREX process by loading the crown ether extractant with stable Sr.

The Run \#64 pilot plant calcine was dissolved in $5 \mathrm{MHNO}_{3}$ at a ratio of $10 \mathrm{~L}$ of acid per $1 \mathrm{Kg}$ of calcine. The solution was heated to near boiling temperature $\left(\approx 95^{\circ} \mathrm{C}\right)$ for 30 minutes. Approximately $95 \%$ of the Run \#64 calcine is dissolved under these conditions. The dissolved calcine solution was filtered through a 0.45 micron filter. It is expected that the SREX process would follow the TRUEX process when treating dissolved INTEC zirconium calcine. Therefore for the flowsheet testing, $750 \mathrm{~mL}$ of $0.1 \mathrm{MNH}_{4} \mathrm{~F}$ in $0.7 \mathrm{MHNO}_{3}$ was added to $750 \mathrm{~mL}$ of the dissolved Run \#64 calcine in order to simulate the composition of the TRUEX raffinate. Hydrogen peroxide $\left(2.5 \mathrm{~mL}\right.$ of $\left.35 \% \mathrm{H}_{2} \mathrm{O}_{2}\right)$ was added to the dissolved calcine feed to reduce the $\mathrm{Cr}^{+6}$ to $\mathrm{Cr}^{+3}$ and prevent its extraction. ${ }^{85} \mathrm{Sr}$ was also added to the dissolved Run \#64 calcine. The composition of the resulting dissolved Run \#64 calcine is given in Table 2 .

Table 2. Dissolved Run \#64 pilot plant calcine SREX feed composition.

\begin{tabular}{cc}
\hline Component & Concentration \\
\hline $\mathrm{Al}(M)$ & 0.14 \\
$\mathrm{~B}(M)$ & 0.028 \\
$\mathrm{Ca}(M)$ & 0.33 \\
$\mathrm{Cr}(M)$ & 0.003 \\
$\mathrm{Ce}(M)$ & $8.9 \mathrm{E}-06$ \\
$\mathrm{Fe}(M)$ & 0.0037 \\
$\mathrm{H}^{+}(M)$ & 1.17 \\
$\mathrm{~K}(M)$ & 0.0064 \\
$\mathrm{Na}(M)$ & 0.07 \\
$\mathrm{Ni}(M)$ & 0.0004 \\
$\mathrm{Zr}(M)$ & 0.065 \\
${ }^{85} \mathrm{Sr}(\mathrm{dps} / \mathrm{mL})$ & 2,480 \\
\hline
\end{tabular}

\section{SREX Solvent}

The SREX solvent composition used in all SREX flowsheet studies reported herein was $0.15 \mathrm{M}$ 4',4'(5')-di-(tert-butylcyclohexo)-18-crown-6 and 1.5 M TBP in Isopar-L ${ }^{\circledR}$ and was prepared by the ICPP Quality Control Laboratory. The extractant was obtained from Eichrom Industries, Darien, Il. The performance of this extractant is extremely sensitive to the purity of the product. The extractant used in 
these tests was reported to yield a $\mathrm{D}_{\mathrm{Sr}}$ value of 3.8 according to Eichrom quality assurance procedures. The SREX process was originally developed using 1-octanol as the diluent. This selection was made because the flash point and flammability of this diluent were determined to present minimal risk in a process operation. However, octanol is known to form degradation products when placed in contact with nitric acid. The degradation products present unknown potential safety problems in the operation of the SREX process. In addition, it has been determined that the residual presence of 1-octanol in the aqueous phase decreases the performance of CMPO in actinide removal in the TRUEX process during sequential waste treatment processes. An alternative diluent, therefore, has been studied to replace 1-octanol. The alternative solvent is composed of an isoparaffinic hydrocarbon diluent (Isopar-L ${ }^{\circledR}$ from Exxon Corp.) and 1.5 $M$ TBP as a phase modifier. This solvent is compatible with the TRUEX solvent currently being studied at the INTEC.

Approximately 1,175 mL of SREX solvent was available from previous SREX flowsheet testing. This solvent was washed with 0.01 $M$ EDTA two times at an organic to aqueous phase ratio (O/A) of 1.0 to remove any $\mathrm{Hg}$ from the solvent. $\mathrm{Hg}$ is extracted from SBW but not effectively stripped with the current SREX flowsheet. Therefore, $\mathrm{Hg}$ was present in the SREX solvent from the previous testing. EDTA is known to strip $\mathrm{Hg}$ from the solvent. ${ }^{10}$ After the EDTA wash, $450 \mathrm{~mL}$ of unused SREX solvent made up in 1997 and $400 \mathrm{~mL}$ of new SREX solvent were added and the combined solvent was washed

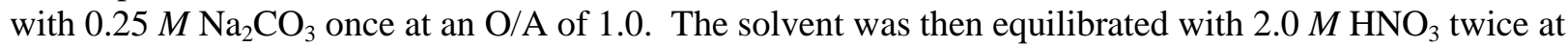
an O/A of 1.0. The purity and composition of the SREX solvent is established prior to use in the centrifugal contactors. $\mathrm{D}_{\mathrm{Sr}}$ was determined using the washed SREX solvent (pre-equilibrated with $3.0 \mathrm{M}$ $\mathrm{HNO}_{3}$ ) and 3.0 $M \mathrm{HNO}_{3}$ solution in order to evaluate solvent purity and composition. This method of determining the strontium distribution coefficient was established as a quality control procedure for testing the initial SREX solvent and the SREX solvent product from each flowsheet test. If the results were within the acceptable range $\left(D_{\mathrm{Sr}}>6\right)$, the solvent was considered suitable for extraction studies. A $\mathrm{D}_{\mathrm{Sr}}$ of only 4.5 was obtained for the washed solvent as compared to a $\mathrm{D}_{\mathrm{Sr}}$ of 7.1 for freshly prepared and washed solvent. As a result of the low distribution coefficient for $\mathrm{Sr}$ it was determined that this solvent was not suitable for use in the flowsheet testing. Fresh solvent $(1,400 \mathrm{~mL})$ was prepared, washed, and equilibrated as described above. All of the currently available crown ether was used for this solvent makeup so it became necessary to add $600 \mathrm{~mL}$ of the old solvent for a total volume of $2,000 \mathrm{~mL}$. Solvent purity testing of this $2,000 \mathrm{~mL}$ of solvent yielded a $\mathrm{D}_{\mathrm{Sr}}$ of 8.4 which is acceptable for flowsheet testing.

It is unknown why the SREX solvent from the previous testing yielded such a low Sr distribution coefficient. The solvent was used for flowsheet testing in March of 1997. This solvent, which contained approximately 1.0 M HNO3, remained in the shielded cell facility until testing in August of 1998. It is expected that hydrolytic and radiolytic degradation of the solvent occurred. It is impossible to estimate the radiological dose received by the SREX solvent in the shielded cell due to the variety of testing and analyses that are performed in the cell.

Prior to performing the flowsheet testing, the SREX solvent was pre-equilibrated with $\mathrm{HNO}_{3}$ by contacting the solvent with $3 \mathrm{MHNO}_{3}$ twice at an $\mathrm{O} / \mathrm{A}=1$. With this pre-equilibration, the $\mathrm{HNO}_{3}$ concentration of the SREX solvent feed was approximately 1.0 M. Pre-equilibration of the solvent prevents the extraction of $\mathrm{HNO}_{3}$ from the acidic waste, which would result in lower ${ }^{90} \mathrm{Sr}$ distribution coefficients in the extraction section.

\section{Analytical}

The laboratory batch contact testing and the countercurrent extraction tests that were performed resulted in a considerable number of samples requiring analysis. Analyses for this testing included ${ }^{85} \mathrm{Sr}$, stable $\mathrm{Sr}, \mathrm{Al}, \mathrm{B}, \mathrm{Ca}, \mathrm{Cr}, \mathrm{Fe}, \mathrm{H}^{+}, \mathrm{Ni}, \mathrm{K}, \mathrm{Na}$, and $\mathrm{Zr}$. Gamma spectroscopy was used for ${ }^{85} \mathrm{Sr}$ analyses. Inductively coupled plasma atomic emission spectroscopy (ICP-AES) was used for Al, B, Ca, Cr, Fe, Ni, $\mathrm{Sr}$, and $\mathrm{Zr}$ analyses and atomic absorption spectrophotometry (AAS) for $\mathrm{Na}$ and $\mathrm{K}$ analyses. 
Analysis of the organic samples could not be performed directly, with the exception of ${ }^{85} \mathrm{Sr}$. Therefore, the components of interest were stripped from the organic samples and the resulting aqueous strip solution was submitted for analysis. Previous experimental work indicated that $\mathrm{Al}, \mathrm{B}, \mathrm{Ca}, \mathrm{Cr}, \mathrm{Fe}$, $\mathrm{Ni}, \mathrm{K}, \mathrm{Na}$, and $\mathrm{Zr}$ are effectively back-extracted from the SREX solvent with solutions of EDTA. ${ }^{10}$ Consequently, the SREX solvent samples were contacted with 0.1 $M$ EDTA. The resulting aqueous solutions were used for the indirect analysis of the organic phase. An organic to aqueous (O/A) phase ratio of 0.2 was used in these contacts, and two separate contacts were performed, to insure quantitative recovery of extracted species from the organic phase occurred.

\section{SREX Laboratory Batch Contacts With Dissolved Run \#64 Calcine}

Prior to performing the SREX countercurrent flowsheet testing, a batch contact flowsheet test was performed. The batch contact flowsheet test, as shown in Figure 2, was performed in a crosscurrent method using solution compositions and O/A ratios similar to the proposed countercurrent flowsheet test. The dissolved Run \#64 calcine was adjusted to simulate TRUEX raffinate by adding $0.1 \mathrm{M}$ ammonium fluoride. Small volume $(10-50 \mathrm{~mL})$ glass centrifuge tubes were used to perform the batch contacts. Measured volumes of the appropriate organic phase and aqueous phase were dispensed into the centrifuge tubes with an automatic motorized pipette (Rainin, Inc.). The two phases were then mixed on a vortexmotion mixer for sixty seconds. Separation of the resulting emulsion was accomplished by centrifugation at 5,000 rpm for one minute. The phases were removed from the test tubes by glass Pasteur pipettes and measured aliquots were taken from each phase for analytical measurements.

\section{SREX Flowsheet Testing With Dissolved Run \#64 Calcine}

Based on the results of the SREX batch laboratory extraction experiments performed, a SREX flowsheet was recommended for testing in the 2-cm centrifugal contactors. This flowsheet consists of ten stages of extraction at an O/A of 1.0, two stages of $1 M \mathrm{NaNO}_{3}$ scrub at an O/A of 4.0, four stages of $0.01 M \mathrm{HNO}_{3}$ strip at an $\mathrm{O} / \mathrm{A}$ of 0.5 , two stages of $0.25 \mathrm{M} \mathrm{Na}_{2} \mathrm{CO}_{3}$ wash at an $\mathrm{O} / \mathrm{A}$ of 1.0, and two stages of $0.1 \mathrm{MHNO}_{3}$ rinse at an $\mathrm{O} / \mathrm{A}$ of 2.0. The resulting flowsheet used for the SREX flowsheet testing with dissolved pilot plant calcine is shown in Figure 3. It should be noted that the solvent was not recycled during this testing. Typically, two stages of $3 \mathrm{MHNO}_{3}$ equilibration would follow the acid rinse. Equipment setup allows flowsheet testing with a maximum of five sections. Since the solvent was not recycled, the equilibration section was not included in the flowsheet.

SREX flowsheet testing was performed as follows. The centrifugal contactor motors were started at 3,600 rpm. All aqueous solution flows, except for the dissolved Run \#64 feed, were established. A $1.0 \mathrm{M}$ $\mathrm{HNO}_{3}$ solution was used as the feed solution during startup. When aqueous solution was observed exiting each of the sections, solvent flow was initiated. Dissolved Run \#64 calcine feed (spiked with ${ }^{85} \mathrm{Sr}$ ) was started when solvent was observed exiting the acid rinse section (stage 20). Samples were taken from the aqueous raffinate and strip product at intervals of 30,60, and 90 minutes after the start of the dissolved calcine feed. Level readings on each of the feed tanks were also noted in order to determine actual solution flowrates based on tank depletion rates. Approximately 120 to 150 minutes after the start of feed, samples were taken of the aqueous raffinate, strip product, wash effluent, rinse effluent, and solvent effluent streams. Also, from 98 to 124 minutes after the start of spiked feed a composite raffinate sample was taken. The centrifugal contactors were shutdown by simultaneously stopping the feed pumps and contactor motors. Each stage remains approximately at steady-state operating conditions with this type of shutdown. This allowed aqueous and organic samples to be taken from each stage and, therefore, distribution coefficients to be determined for any of the 20 stages. 


\section{SREX Solvent}

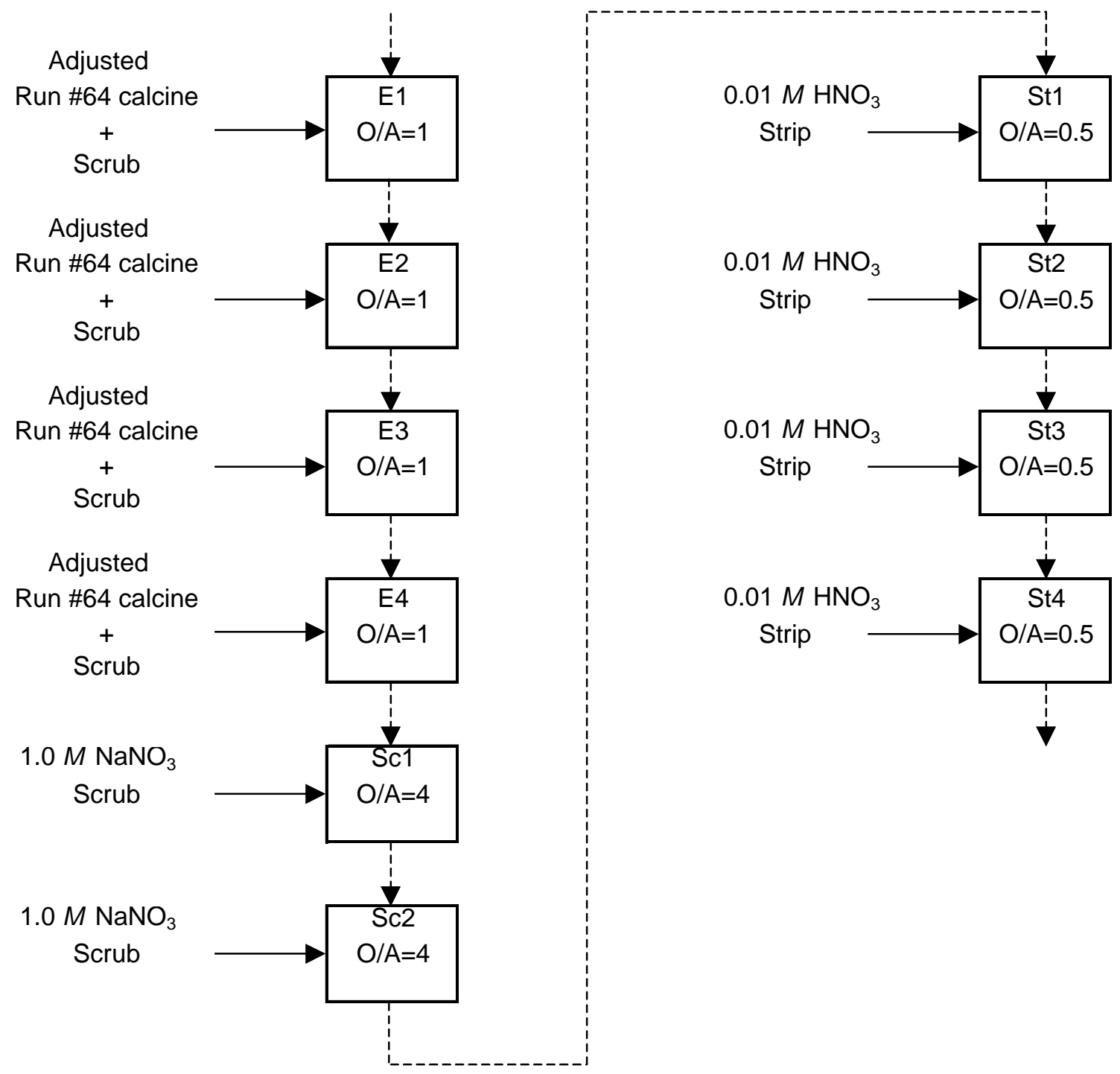

Figure 2. SREX batch contact flowsheet with dissolved Run \#64 calcine.

After shutdown, individual stage samples were taken as follows. The solution from each stage was drained into individual $60 \mathrm{~mL}$ sample bottles. The phases were re-equilibrated by shaking the bottles for several minutes each. Re-equilibration of the phases serves to evaluate distribution coefficients of the individual species under hypothetical conditions of $100 \%$ stage efficiency. The re-equilibrated solution from each stage was then poured into a clean separatory funnel, allowed to stand for five to ten minutes, and the aqueous and organic phases were separated. 


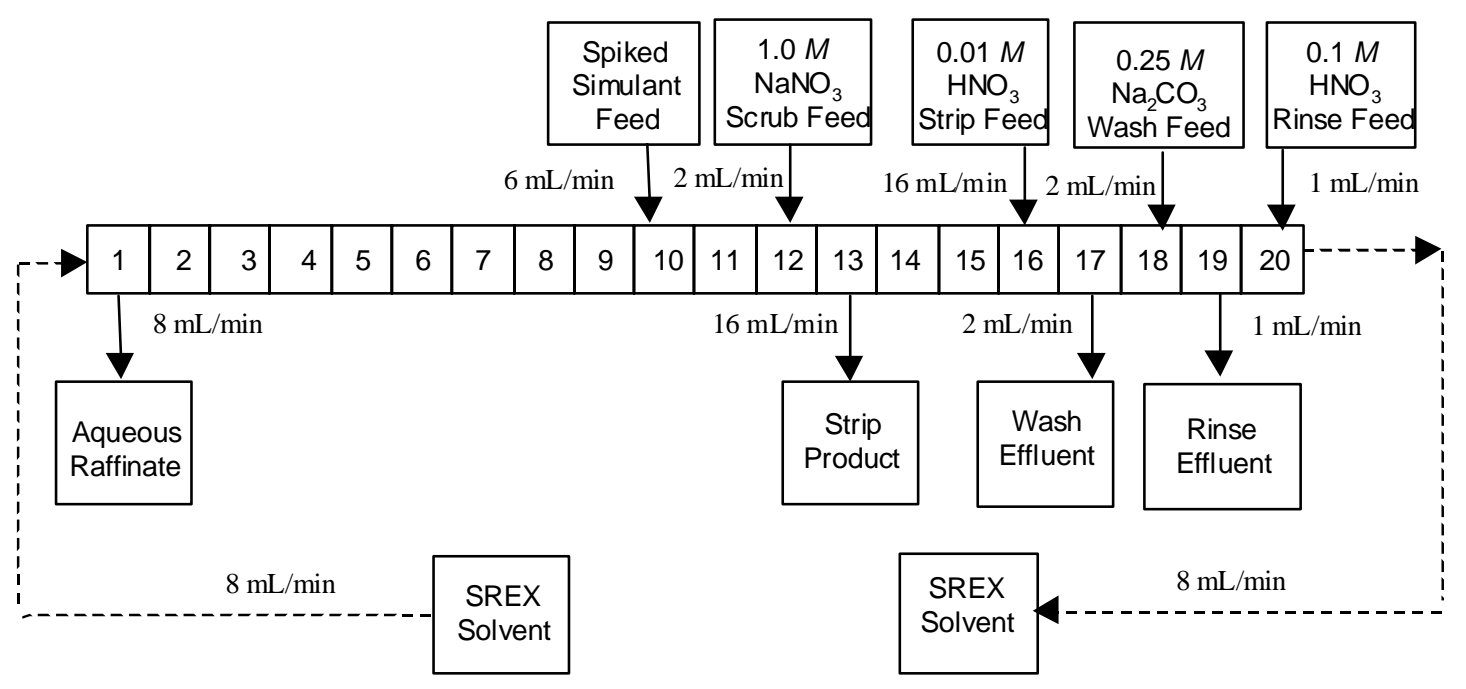

Figure 3. Flowsheet for SREX testing with dissolved Run \#64 calcine. 


\section{RESULTS AND DISCUSSION}

\section{SREX Laboratory Batch Contacts With Dissolved Run \#64 Calcine}

The fundamental chemistry of extraction from dissolved Run \#64 calcine by the SREX solvent was studied in small volume batch solvent extraction contacts to provide the basis for design of the countercurrent flowsheet experiments. This approach has been employed previously in the development of the SREX process for SBW. Batch contact laboratory studies provided data which was incorporated into the design process for countercurrent testing of simulated SBW in 5.5-cm and 2-cm centrifugal contactors. This work led to eventual testing with actual SBW in a 2-cm centrifugal contactor pilot plant. The successful demonstration of the SBW flowsheet was a coordinated effort between laboratory testing and flowsheet engineering.

The batch contact studies performed with dissolved Run \#64 calcine have similarly supported the development of a countercurrent flowsheet with simulated dissolved calcine waste. It is expected that this work will support the further development and eventual demonstration of the treatment process with actual calcine waste.

There are several important differences between liquid SBW and the dissolved calcine wastes which are relevant to the SREX process. One of the most influential differences is the acid concentration. This is a parameter which has been found to be an influential factor in SREX process chemistry. The extraction of $\mathrm{K}^{+}$in the previous SBW development program was significantly higher than expected based upon laboratory studies. This led to the presence of large concentrations of $\mathrm{K}$ in the high activity waste stream containing the segregated ${ }^{90} \mathrm{Sr}$ product. Since this factor is likely to negatively effect the vitrification of the high-level waste stream, laboratory studies were performed with the goal of studying the chemistry of $\mathrm{K}$ in the treatment flowsheets. It has been determined that the extraction of the $\mathrm{K}^{+}$ion by the SREX solvent is highly dependent upon the concentration of the $\mathrm{H}_{3} \mathrm{O}^{+}$(hydronium) ion. This is a unique property of $\mathrm{K}$ and is not observed for other extractable ions. Figure 4 compares this dependence for $\mathrm{K}$ and $\mathrm{Sr}$ ions.

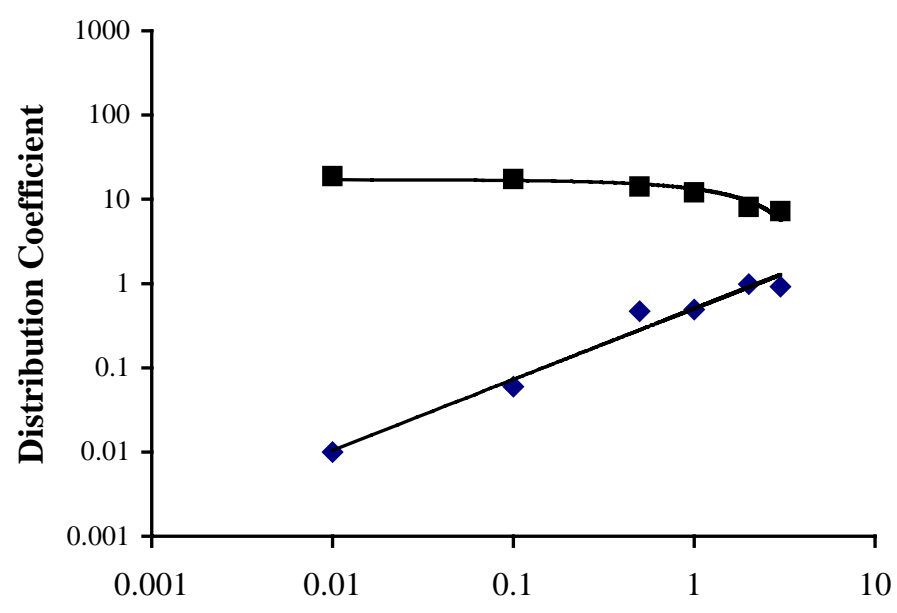

Hydronium Ion Concentration $(M)$

Figure 4. Dependence of $\mathrm{K}(\diamond)$ and $\operatorname{Sr}(\mathbf{I})$ extraction on hydronium ion concentration. Aqueous phase: 3.5 $M$ nitrate ion with $0.001 M \mathrm{KNO}_{3}$ or $0.001 M \mathrm{Sr}\left(\mathrm{NO}_{3}\right)_{2}$, adjusted with $\mathrm{LiNO}_{3}$ and $\mathrm{HNO}_{3}$. 
The previous development of the SBW flowsheet employed a nitric acid scrub procedure. It is clear from subsequent laboratory testing that the use of a scrub solution which has a high concentration of hydronium ion is ineffective for scrubbing $\mathrm{K}$ from the organic phases, since the distribution coefficient for $\mathrm{K}$ is directly related to the acid concentration. Therefore, laboratory batch contact experiments for the development of the Run \#64 calcine flowsheets employed the use of a sodium nitrate scrub solution in order to more effectively scrub $\mathrm{K}$ from the organic solvent.

Preliminary batch contact studies identified two separate problems in the use of the SREX solvent for removal of $\mathrm{Sr}$ from the dissolved Run \#64 calcine. The first problem was observed in extraction contacts with the SREX solvent and the dissolved calcine solution. Although the solution remained clear during contacts and phase separation, within two hours after phase separation, a thick white precipitate formed in the organic phase. Laboratory studies indicated that the addition of fluoride ion in the form of ammonium fluoride to the simulated waste solution prior to contact with the SREX solvent eliminated the formation of this precipitate. Ammonium fluoride is used as a scrub solution in the TRUEX process flowsheet for calcine treatment. This results in the presence of ammonium fluoride in the raffinate from TRUEX. Thus, a processing scheme which is designed to use the TRUEX raffinate as the feed for the SREX process would function well by providing the ammonium fluoride necessary for the SREX process. In other processing designs, the SREX feed would need to be adjusted prior to processing by the addition of ammonium fluoride reagent. Analytical confirmation of the composition of the precipitate has not been completed. However, some evidence indicates that the precipitate may be primarily composed of a calcium complex with the extractant. This complex slowly precipitates over time and resides at the phase boundary.

The second problem encountered in the batch contacts was observed in the strip procedure which removes the extracted metals from the organic phase after the contacts with the dissolved Run \#64 calcine solution. After several contacts with dilute nitric acid, a white precipitate forms at the interface of the two phases. It is believed that this precipitate results from the presence of co-extracted Cr. Laboratory experiments show that addition of hydrogen peroxide to the dissolved Run \#64 calcine solution prior to the extraction contacts prevents the eventual appearance of the precipitate in the stripping procedure. It was also shown that the presence of $1 M$ citric acid would accomplish the same result as the hydrogen peroxide addition. However, since hydrogen peroxide does not introduce any organic mass to the system, it is viewed as a preferable reagent.

The preparation of the Run \#64 calcine solution for treatment with the SREX process flowsheet incorporated both of the above techniques. The feed was adjusted by the addition of $0.1 \mathrm{M}$ ammonium fluoride and a small volume $(0.1 \mathrm{~mL})$ of $30 \%$ hydrogen peroxide. The volume ratio for feed:0.1 $M$ ammonium fluoride:1.0 $M$ sodium nitrate was $4: 2: 1.5$. These values were selected to be chemically similar to a TRUEX raffinate solution.

The batch contact flowsheet shown in Figure 2 was determined to be effective in the removal of $\mathrm{Sr}$ from the dissolved calcine waste solutions. The flowsheet was found to be free of precipitate formation and third phase formation. The concentrations of several components of the simulated waste solution in the aqueous phases of the contacts in the flowsheet are shown in Table 3. The calculated distribution coefficients for $\mathrm{Na}, \mathrm{K}, \mathrm{Ca}, \mathrm{Sr}, \mathrm{Al}, \mathrm{Zr}, \mathrm{Fe}, \mathrm{Hg}$, and $\mathrm{Pb}$ determined by mass balance calculations using analytical results from the aqueous phases from the batch contact flowsheet are shown in Table 4.

The mass of the metal ions as a percentage of the total metals in solution is given in Table 5. The batch contacts indicate that the mass fraction of $\mathrm{Sr}$ is increased by a factor of 145 upon separation from the bulk of the waste solution. It is important to note that the total mass of metals present in the St1 aqueous phase is approximately $159 \mathrm{mg}$ metals/L, the majority of that mass being $\mathrm{Na}$ (extracted from the sodium nitrate scrub solution) and $\mathrm{Sr}$. This is compared to $30,000 \mathrm{mg}$ metal/L in the original waste solution. The total metal mass reduction in this separation process is $99.54 \%$. 
Table 3. Concentrations $(\mathrm{mg} / \mathrm{L})$ of aqueous phase metals in batch contacts.

\begin{tabular}{cccccccccc}
\hline Sample & $\mathrm{Na}$ & $\mathrm{K}$ & $\mathrm{Ca}$ & $\mathrm{Al}$ & $\mathrm{Fe}$ & $\mathrm{Sr}$ & $\mathrm{Zr}$ & $\mathrm{Pb}$ & $\mathrm{Hg}$ \\
\hline Feed & 5,600 & 284 & 13,783 & 3,999 & 238 & 41.5 & 6,196 & bdl & 0.358 \\
E 1 & 5,780 & 214 & 13,431 & 4,037 & 222 & 11.3 & 6,224 & bdl & 0.0082 \\
E 2 & 7,180 & 260 & 13,508 & 4,023 & 216 & 20 & 6,346 & bdl & bdl \\
E 3 & 8,120 & 275 & 13,596 & 3,886 & 230 & 26.2 & 6,109 & bdl & 0.009 \\
E 4 & 5,780 & 305 & 14,267 & 4,095 & 232 & 29.2 & 6,580 & bdl & 0.008 \\
Sc 1 & 20,200 & 194 & 68.3 & 38.1 & 231 & 46.8 & 235 & bdl & bdl \\
Sc 2 & 21,600 & 110 & 53.4 & 3.47 & 0.371 & 53.5 & 16.3 & bdl & bdl \\
St 1 & 118 & 7.14 & 1.96 & bdl $^{\text {a }}$ & 0.0748 & 32.5 & bdl & bdl & bdl \\
St 2 & 3.03 & 2.29 & 1.28 & bdl & bdl & 0.87 & bdl & bdl & bdl \\
St 3 & 2.28 & 0.097 & 1.032 & bdl & bdl & bdl & bdl & bdl & bdl \\
St 4 & 2.81 & 0.135 & 2.84 & bdl & 0.145 & bdl & 0.253 & bdl & bdl \\
\hline
\end{tabular}

a. bdl indicates a concentration below the analytical detection limit.

Table 4. Estimated distribution coefficients for components in batch contacts.

\begin{tabular}{cccccccccc}
\hline Sample & $\mathrm{Na}$ & $\mathrm{K}$ & $\mathrm{Ca}$ & $\mathrm{Al}$ & $\mathrm{Fe}$ & $\mathrm{Sr}$ & $\mathrm{Zr}$ & $\mathrm{Hg}$ & $\mathrm{Pb}$ \\
\hline E 1 & $<0.01$ & 0.34 & 0.01 & $<0.01$ & 0.07 & 2.67 & $<0.01$ & 42.61 & $\mathrm{bdl}^{\mathrm{a}}$ \\
E 2 & $<0.01$ & 0.39 & 0.02 & $<0.01$ & 0.18 & 2.59 & $<0.01$ & $>40$ & \\
E 3 & $<0.01$ & 0.41 & 0.02 & $<0.01$ & 0.20 & 2.56 & $<0.01$ & $>40$ & \\
E 4 & $<0.01$ & 0.31 & 0.02 & $<0.01$ & 0.22 & 2.72 & $<0.01$ & $>40$ & \\
Sc 1 & & 0.24 & 0.01 & & $<0.01$ & 1.44 & & $>40$ & \\
Sc 2 & & 0.18 & $<0.01$ & & $<0.01$ & 1.01 & & $>40$ & \\
St 1 & & 0.71 & $<0.01$ & & $<0.01$ & $<0.01$ & & $>40$ & \\
St 2 & & 0.20 & $<0.01$ & & $<0.01$ & $<0.01$ & & $>40$ & $>40$ \\
St 3 & & 2.78 & $<0.01$ & & $<0.01$ & $<0.01$ & & $>40$ & \\
St 4 & & 0.00 & $<0.01$ & & $<0.01$ & $<0.01$ & & $>40$ & \\
\hline
\end{tabular}

a. bdl indicates a concentration below the analytical detection limit.

Table 5. Mass percentages of metal ions in aqueous solutions.

\begin{tabular}{ccccccc}
\hline & $\mathrm{Sr}$ & $\mathrm{K}$ & $\mathrm{Na}$ & $\mathrm{Zr}$ & $\mathrm{Al}$ & $\mathrm{Ca}$ \\
\hline Feed & 0.14 & 0.94 & 18.6 & 20.6 & 13.3 & 45.7 \\
St1 & 20.4 & 4.5 & 73.9 & 0 & 0 & 1.2 \\
\hline
\end{tabular}

It should be noted that the distribution coefficients for $\mathrm{Sr}$ in the batch contacts were significantly lower (approximately 2.5) in this flowsheet than expected. These values may be due to the fact that the feed was diluted significantly with ammonium fluoride and sodium nitrate. This dilution decreased the concentration of nitrate and hydronium ion in the solution resulting in decreased $\mathrm{Sr}$ extraction. The values are still high enough to provide an efficient process. Another factor contributing to these low values may include a lower purity of the extractant DtBuCH18C6. The values for the Sr distribution coefficient in the countercurrent testing were significantly higher (vide infra). 


\section{SREX Flowsheet Testing With Dissolved Run \#64 Calcine}

\section{Contactor Operation}

Actual solution flowrates were calculated from feed tank depletion rates and are compared to the desired flowrates in Table 6. Precipitate and/or third phase formation were not observed during testing or after shutdown. Also, no observable flooding occurred.

Table 6. Flowrates and O/A ratios for SREX flowsheet testing with dissolved Run \#64 calcine.

\begin{tabular}{lcccccc}
\hline \multirow{2}{*}{ Section } & & \multicolumn{2}{c}{ Flowrate $(\mathrm{mL} / \mathrm{min})$} & \multicolumn{2}{c}{ O/A Ratio } & \multicolumn{2}{c}{ Total Flow } \\
All & Phase & Desired & Actual & Desired & Actual & (mL/min $)$ \\
Extraction & Org. & 8.0 & 7.6 & --- & --- & -- \\
Scrub & Aq. & 8.0 & 7.6 & 1.0 & 1.0 & 15.2 \\
Strip & Aq. & 2.0 & 2.0 & 4.0 & 3.8 & 9.6 \\
$\mathrm{Na}_{2} \mathrm{CO}_{3}$ Wash & Aq. & 16.0 & 16.0 & 0.5 & 0.48 & 23.6 \\
$\mathrm{HNO}_{3}$ Rinse & Aq. & 2.0 & 2.0 & 4.0 & 3.8 & 9.64 \\
\hline
\end{tabular}

\section{Time to Reach Steady State}

The activity of ${ }^{85} \mathrm{Sr}$ as a function of time ( $\mathrm{T}_{0}=$ start of spiked dissolved Run \#64 calcine feed flow) is given in Figure 5 for the aqueous raffinate and strip product streams. Steady state was reached within 30 minutes in the strip product and within 60 minutes in the aqueous raffinate. It was assumed that steady state was reached when the activity of ${ }^{85} \mathrm{Sr}$ varied by less than ten percent.

\section{Concentrations at Shutdown}

The concentrations of ${ }^{85} \mathrm{Sr}, \mathrm{Na}, \mathrm{K} \mathrm{Al}, \mathrm{B}, \mathrm{Ca}, \mathrm{Cr}, \mathrm{Fe}, \mathrm{Ni}$, and $\mathrm{Zr}$ were determined in each effluent stream immediately prior to shutdown. The resulting material balances for each component are given in Table 7. Distribution coefficients were calculated for ${ }^{85} \mathrm{Sr}$ for several of the 24 stages. The resulting distribution coefficients are given in Table 8. A discussion of the behavior of each component follows.

${ }^{85}$ Strontium. The ${ }^{85} \mathrm{Sr}$ activity was reduced from $2.48 \mathrm{E}+03 \mathrm{dps} / \mathrm{mL}$ in the feed to $7.9 \mathrm{dps} / \mathrm{mL}$ in the raffinate. This corresponds to a removal efficiency of $99.6 \%$. This is sufficient to reduce the ${ }^{90} \mathrm{Sr}$ activity in actual dissolved calcine to approximately $0.5 \mathrm{Ci} / \mathrm{m} 3$, which is below the NRC Class B LLW criteria of $150 \mathrm{Ci} / \mathrm{m}^{3}$ but above the NRC Class A LLW criteria of $0.04 \mathrm{Ci} / \mathrm{m}^{3}$. Distribution coefficients in the extraction section ranged from 3.6 to 4.5 . With these distribution coefficients it is expected that a much greater removal efficiency would have been obtained for ${ }^{85} \mathrm{Sr}$. The extraction distribution coefficients were used in conjunction with the Generic TRUEX model in order to evaluate stage efficiencies. ${ }^{13}$ As shown in Figure 6, for $100 \%$ stage efficiency the activity of ${ }^{85} \mathrm{Sr}$ would have been reduced to $0.02 \mathrm{dps} / \mathrm{mL}$ (99.999\% removal efficiency). With an average stage efficiency of $60 \%$ in the extraction section, the predicted aqueous phase stage data are in good agreement with the experimental data. 


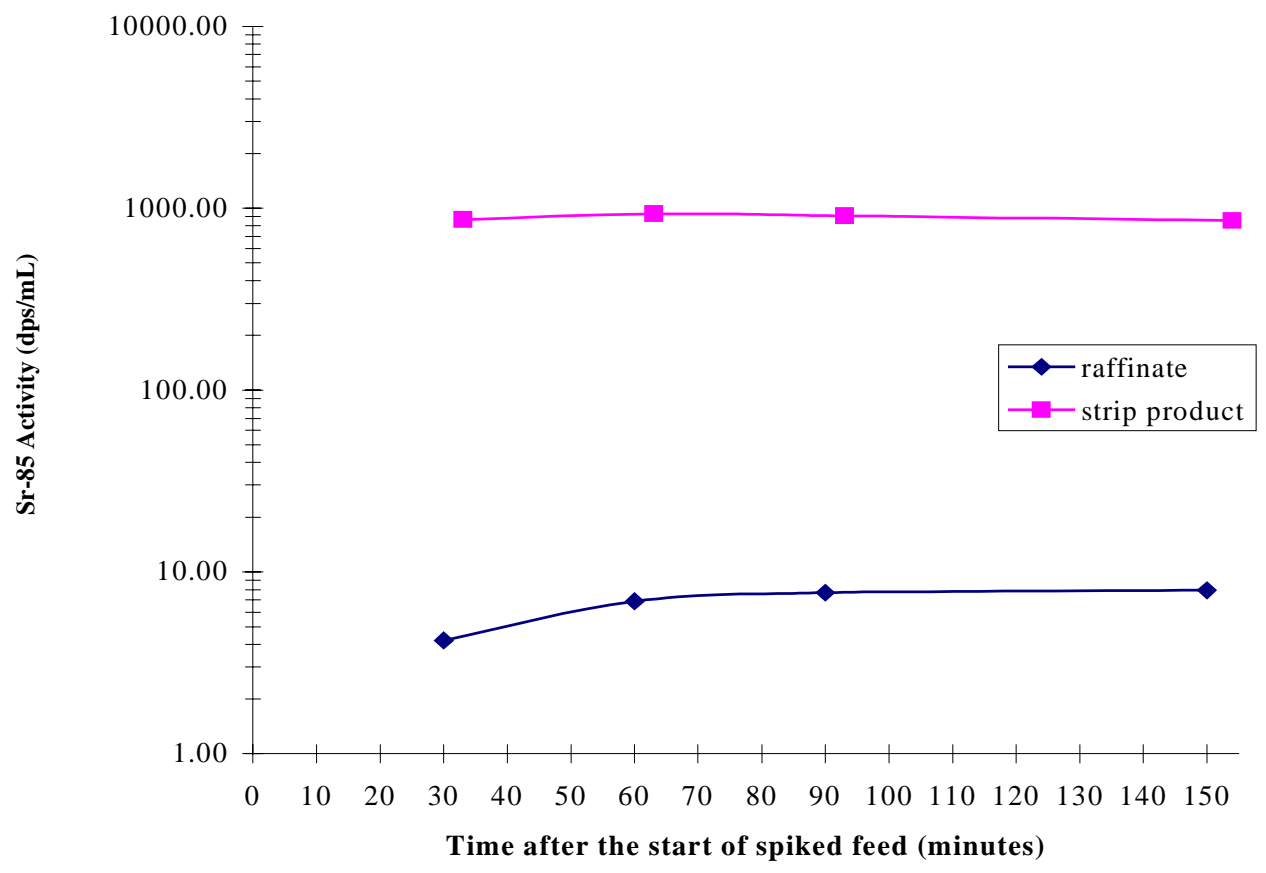

Figure 5. ${ }^{85} \mathrm{Sr}$ approach to steady state in the aqueous raffinate and strip product.

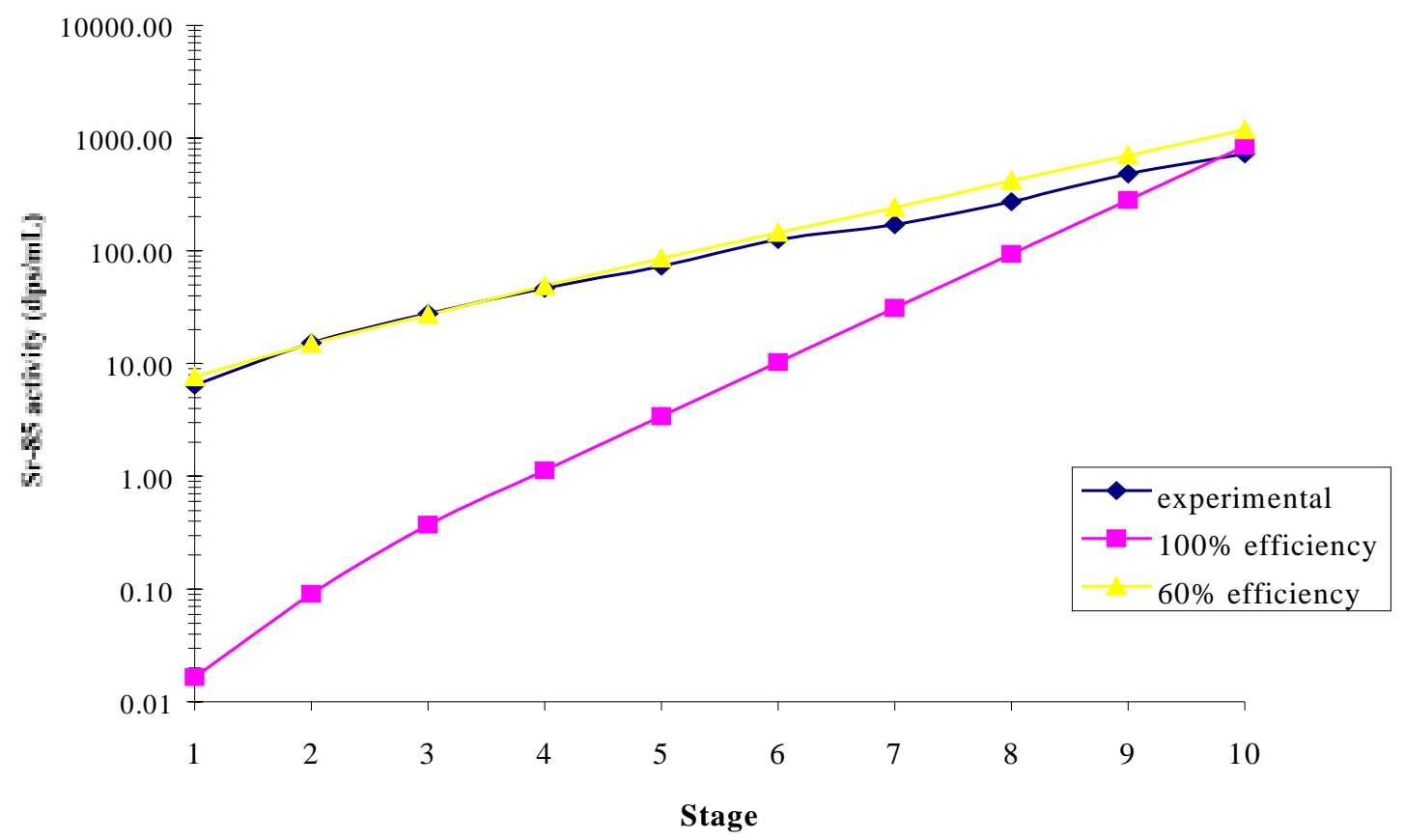

Figure 6. Comparison of experimental aqueous phase activities with GTM predicted activities for each of the extraction stages as a function of stage efficiency. 
Table 7. Percentage of component in each of the effluent streams for SREX flowsheet testing with dissolved Run \#64 calcine.

\begin{tabular}{lccccc}
\hline Stream & ${ }^{85} \mathrm{Sr}$ & $\mathrm{Na}^{\mathrm{b}}$ & $\mathrm{K}$ & $\mathrm{Al}$ & $\mathrm{B}$ \\
\hline Aqueous Raffinate & $0.43 \%$ & $85.4 \%$ & $92.3 \%$ & $98.5 \%$ & $87.5 \%$ \\
Strip Product & $97.7 \%$ & $1.5 \%$ & $6.4 \%$ & $<0.04 \%$ & $1.2 \%$ \\
$\mathrm{Na}_{2} \mathrm{CO}_{3}$ Effluent & $<0.01 \%$ & $34.8 \%$ & $0.006 \%$ & $<0.005 \%$ & $0.02 \%$ \\
Acid Rinse Effluent & $<0.002 \%$ & $0.94 \%$ & $0.004 \%$ & $<0.002 \%$ & $<0.007 \%$ \\
Solvent Effluent & $<0.02 \%$ & --- & --- & $<0.44 \%$ & $2.4 \%$ \\
Mass Balance & $98.2 \%$ & $122.7 \%$ & $98.7 \%$ & $99 \%$ & $91.1 \%$ \\
\hline Stream & $\mathrm{Ca}$ & $\mathrm{Cr}$ & $\mathrm{Fe}$ & $\mathrm{Ni}$ & $\mathrm{Zr}$ \\
\hline Aqueous Raffinate & $100.5 \%$ & $96.0 \%$ & $102.7 \%$ & $105.3 \%$ & 97.6 \\
Strip Product & $0.006 \%$ & $<0.15 \%$ & $<0.13 \%$ & $<1.9 \%$ & $<0.012 \%$ \\
Na ${ }_{2} \mathrm{CO}_{3}$ Effluent & $0.001 \%$ & $<0.02 \%$ & $<0.016 \%$ & $<0.23 \%$ & $<0.002 \%$ \\
Acid Rinse Effluent & $0.0003 \%$ & $<0.008 \%$ & $0.008 \%$ & $<0.11 \%$ & $<0.0007 \%$ \\
Solvent Effluent & $<0.05 \%$ & $<1.5 \%$ & $<2.5 \%$ & $<37.7 \%$ & $<0.24 \%$ \\
Mass Balance & $100.5 \%$ & $96.0 \%$ & $102.7 \%$ & $105 \%-145 \%$ & $97.6 \%$ \\
\hline
\end{tabular}

a. The mass balance is the amount of a component accounted for based on the sample analysis results.

b. Includes the $\mathrm{Na}$ in the scrub and carbonate wash feed streams.

It is not clear why the stage efficiencies were so low on in the extraction stages. Low efficiency has been observed in previous flowsheet testing at the INEEL and at Argonne National Laboratory. ${ }^{9,10}$

The $0.01 M$ nitric acid strip section was very effective in back-extracting the ${ }^{85} \mathrm{Sr}$ from the SREX solvent, resulting in $>99.98 \%$ of the ${ }^{85} \mathrm{Sr}$ being stripped from the SREX solvent with the four strip stages.

Sodium. The concentration of $\mathrm{Na}$ in the strip product was $70 \mathrm{mg} / \mathrm{L}$ which corresponds to $12.3 \%$ of the $\mathrm{Na}$ in the dissolved calcine feed. Typically, $\mathrm{Na}$ is not extracted significantly from the waste solution by the SREX solvent. However, $1 M \mathrm{NaNO}_{3}$ was used as a scrub solution and the slight extraction of the $\mathrm{Na}$ from this solution resulted in a significant amount of $\mathrm{Na}$ in the strip product.

Potassium. Batch contact distribution coefficient data indicate that the $\mathrm{K}$ distribution coefficients in the extraction section will be approximately 0.4 , resulting in $25 \%$ of the K extracted by the SREX solvent. With only $6.4 \%$ of the K exiting in the HLW strip product it appears that the scrub section effectively removed the extracted $\mathrm{K}$ from the solvent. The strip section effectively removed the extracted $\mathrm{K}$ from the SREX solvent with only $0.01 \%$ exiting in the solvent wash and acid rinse effluents.

Aluminum, boron, calcium, chromium, iron, nickel and zirconium. The effluent streams were analyzed for $\mathrm{Al}, \mathrm{B}, \mathrm{Ca}, \mathrm{Cr}, \mathrm{Fe}, \mathrm{Ni}$, and $\mathrm{Zr}$. All of these components were essentially inextractable. Boron was the only component for certain with greater than $1 \%$ in the HLW strip product (1.2\%). 
Table 8. ${ }^{85} \mathrm{Sr}$ distribution coefficients for SREX flowsheet testing with dissolved Run \#64 calcine.

\begin{tabular}{lrc} 
Section & Stage & $\mathrm{D}_{\text {Sr }}$ \\
\hline \multirow{3}{*}{ Extraction } & 1 & \\
& 2 & 4.5 \\
& 3 & 3.9 \\
& 4 & 4.3 \\
& 5 & 4.2 \\
& 6 & 3.7 \\
& 7 & 3.6 \\
Scrub & 8 & 4.2 \\
& 9 & 3.8 \\
Strip & 10 & 3.8 \\
& 11 & 3.8 \\
& 12 & 3.1 \\
Wash & 13 & 2.5 \\
& 14 & 0.19 \\
& 15 & $<0.01$ \\
Rinse & 16 & --- \\
& 17 & --- \\
& 18 & --- \\
& 19 & --- \\
& 20 & --- \\
\hline
\end{tabular}




\section{CONCLUSIONS AND RECOMMENDATIONS}

\section{Conclusions}

The SREX flowsheet developed and tested for the separation of Sr from dissolved zirconium type calcine effectively separated ${ }^{85} \mathrm{Sr}$ from dissolved Run \#64 pilot plant calcine. A removal efficiency of $99.6 \%$ was obtained for ${ }^{85} \mathrm{Sr}$. It was determined that the centrifugal contactor operating efficiency in the extraction section was only $60 \%$. Based on the extraction distribution coefficients obtained for ${ }^{85} \mathrm{Sr}$, a removal efficiency of $>99.99 \%$ can be expected for this flowsheet if centrifugal contactors designed specifically for the SREX process are used. The $0.01 M$ nitric acid strip section was very effective in back-extracting the ${ }^{85} \mathrm{Sr}$ from the SREX solvent, resulting in $>99.98 \%$ of the ${ }^{85} \mathrm{Sr}$ being stripped from the SREX solvent with the four strip stages.

Potassium was effectively scrubbed from the SREX solvent using a $1.0 M \mathrm{NaNO}_{3}$ solution. As a result, only $6.4 \%$ of the $\mathrm{K}$ in the feed exited with the HLW strip product. The use of a $1.0 M \mathrm{NaNO}_{3}$ scrub solution does result in a significant amount of $\mathrm{Na}$ in the HLW strip product ( $70 \mathrm{mg} / \mathrm{L})$. All other metals for which analyses were obtained ( $\mathrm{Al}, \mathrm{B}, \mathrm{Ca}, \mathrm{Cr}, \mathrm{Fe}, \mathrm{Ni}$, and $\mathrm{Zr}$ ) were essentially inextractable. Boron was the only component for certain with greater than $1 \%$ in the HLW strip product $(1.2 \%)$.

Flooding, precipitation, and/or third phase formation were not observed during testing.

\section{Recommendations}

The data from this flowsheet test should be used to update mass balances for the treatment of zirconium type calcine. Further testing of the SREX flowsheet shown in Figure 3 is recommended using actual dissolved zirconium type calcine. If it becomes desirable to reduce the quantity of Na in the HLW strip product, alternative scrub solutions should be investigated. Also, further investigations into the low extraction efficiency obtained for $\mathrm{Sr}$ is recommended. 


\section{REFERENCES}

1. T. A. Todd, A. L. Olson, W. B. Palmer, and J. H. Valentine, "Proposed INEEL Treatment Plan for Liquid Acidic Waste and Calcine," Science and Technology for Disposal of Radioactive Tank Wastes, Plenum Press, 1997.

2. A. L Olson, W. W. Schulz, L. A. Burchfield, C. D. Carlson, J. L. Swanson, and M. C. Thompson, Evaluation and Selection of Aqueous Based Technology for Partitioning Radionuclides from ICPP Calcine, WINCO-1071, February 1993.

3. E. P. Horwitz, D. G. Kalina, H. Diamond, G. F. Vandegrift, and W. W. Schulz, "The TRUEX Process - A Process for the Extraction of the Transuranic Elements from Nitric Acid Wastes Utilizing Modified Purex Solvent" Solvent Extr. Ion Exch., 3(1\&2): 75 (1985).

4. E P. Horwitz, M. L. Dietz, and D. E. Fisher, "Extraction of Strontium from Nitric Acid Solutions Using Dicyclohexano-18-Crown-6 and its Derivatives," Solvent Extr. Ion Exch., $\underline{8}(4 \& 5)$, 557-572, 1990.

5. E. P. Horwitz, M. L. Dietz, and D. E. Fisher, "SREX: A New Process for the Extraction and Recovery of Strontium from Acidic Nuclear Waste Streams," Solvent Extr. Ion Exch.,ㅁ(1), 1-25, 1991.

6. E. P. Horwitz, M. L. Dietz, and D. E. Fisher, "Extraction of Strontium from Acidic Nitrate Media using a Modified PUREX Solvent," Solvent Extr. Ion Exch.,13(1), 1-17, 1995.

7. D. J. Wood, J. D. Law, P. A. Tullock, T. G. Garn, R. D. Tillotson, K. N. Brewer, and T. A. Todd, Development of the SREX Process for the Treatment of ICPP Liquid Wastes, INEEL/EXT-9700831 , August 1997.

8. D. J. Wood and J. D. Law, "Evaluation of the SREX Solvent Extraction Process for the Removal of

${ }^{90} \mathrm{Sr}$ and Hazardous Metals from Acidic Nuclear Waste Solutions Containing High Concentrations of Interfering Alkali Metal Ions,” Sep. Sci. \& Tech., 32(1-4), 241-253, 1997.

9. J. D. Law, D. J. Wood, and R. S. Herbst, SREX Flowsheet Development for the Separation of Strontium from ICPP Sodium-Bearing Waste Using Centrifugal Contactors, INEL-95/0314, September 1995.

10. J. D. Law and D. J. Wood, Development and Testing of a SREX Flowsheet for the Partitioning of Strontium and Lead from Simulated ICPP Sodium-Bearing Waste, INEL-96/0437, November 1996.

11. J. D. Law, D. J. Wood, L. G. Olson, and T. A. Todd, Demonstration of a SREX Flowsheet for the Partitioning of Strontium and Lead from Actual ICPP Sodium-Bearing Waste, INEEL/EXT-9700832, August 1997.

12. R. S. Herbst, J. D. Law, and K. N. Brewer, Baseline TRUEX Flowsheet Development for the Removal of the Actinides from Dissolved INTEC Calcine Using Centrifugal Contactors, INEEL/EXT-9800833, August 1998.

13. G. V. Vandegrift, et. al., "Development and Demonstration of the TRUEX Solvent Extraction Process," Proceedings of Waste Management '93, Tucson, Az, 1993, p. 1045. 


\section{APPENDIX A}

\section{EXPERIMENTAL DATA}


Table A-1. Feed, approach to steady state, and effluent samples for flowsheet testing with spiked dissolved Run \#64 pilot plant calcine.

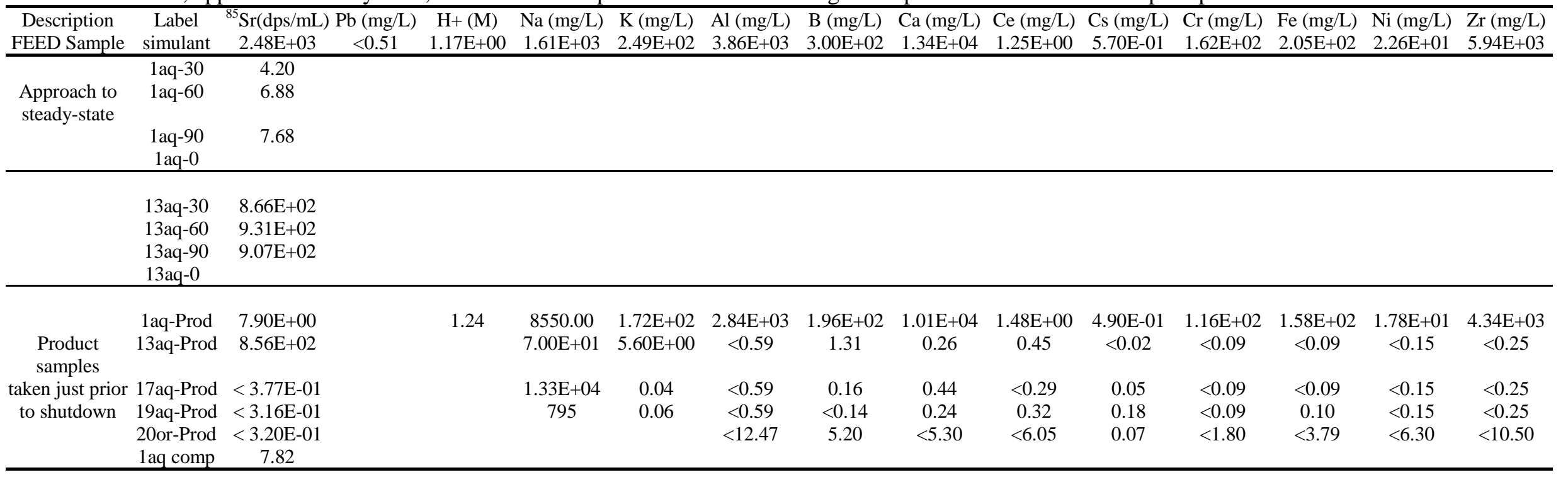


Table A-2. Stage samples for flowsheet testing with spiked dissolved Run \#64 pilot plant calcine.

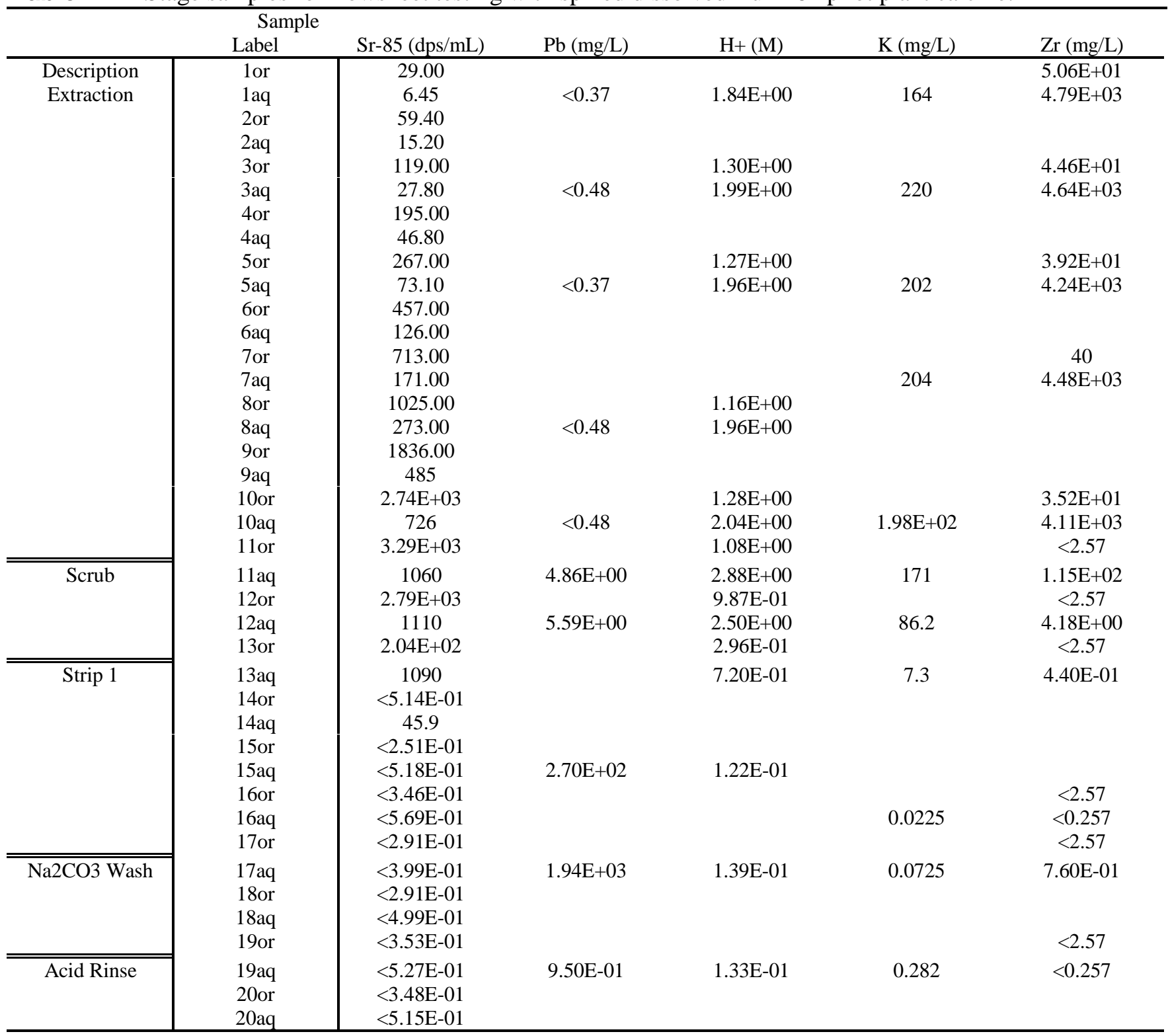

